\title{
A Gravity Model of Sovereign Lending: Trade, Default and Credit
}

\section{Andrew K. Rose and Mark M. Spiegel*}

Draft Revised as of: August 6, 2002

Preliminary: Comments Welcome!

\begin{abstract}
One reason why countries service their external debts is the fear that default might lead to shrinkage of international trade. If so, then creditors should systematically lend more to countries with which they share closer trade links. We develop a simple theoretical model to capture this intuition, then test and corroborate this idea.
\end{abstract}

Keywords: theory, empirical, panel, bilateral, bank, loan, bilateral

JEL Classification Numbers: F15, F33

Andrew K. Rose (correspondence)

Haas School of Business

University of California

Berkeley, CA USA 94720-1900

Tel: (510) 642-6609

Fax: (510) 642-4700

E-mail: arose@haas.berkeley.edu
Mark M. Spiegel

Federal Reserve Bank of San Francisco

101 Market St.

San Francisco CA 94105

Tel: (415) 974-3184

Fax: (415) 974-2168

E-mail: mark.spiegel@sf.frb.org

* Rose is B.T. Rocca Jr. Professor of International Trade and Economic Analysis and Policy in the Haas School of Business at the University of California, Berkeley, NBER research associate and CEPR Research Fellow. Spiegel is Research Advisor, Economic Research Department, Federal Reserve Bank of San Francisco. We thank Rob Feenstra for a comment which helped inspire this paper; Rose thanks INSEAD for hospitality while part of this paper was written. The views expressed below do not represent those of the Federal Reserve Bank of San Francisco or the Board of Governors of the Federal Reserve System, or their staffs. A current (PDF) version of this paper and the STATA data set used in the paper are available at http://faculty.haas.berkeley.edu/arose. 


\section{1: Introduction}

While the age of gunboat diplomacy as a mechanism of credit enforcement has long passed, sovereign default is still an exceptional event. This stylized fact indicates that while the source of a sovereign default penalty is still controversial, sovereigns behave as if they consider default costly. Many models of sovereign debt in the literature [e.g. Bulow and Rogoff (1989a), (1989b)] introduce explicit default penalties to rationalize this fact. These sanctions are primarily considered to be methods of inhibiting trade. Bulow and Rogoff (1989a) discuss the difficulties countries would experience in their trade subsequent to default, including complications associated with avoiding seizure and the interruption of short-term trade credit.

Nevertheless, there are a number of reasons why one might doubt the existence of default penalties. Bulow and Rogoff (1989b) themselves admit that it is unclear whether private creditors enjoy the ability to induce their governments to enforce claims on sovereign borrowers. Kletzer and Wright (2000) argue that most penalties in models of sovereign lending are not "renegotiation-proof." That is, Kletzer and Wright argue that both parties could do better subsequent to a full or partial sovereign default, if the creditor resists levying a destructive penalty from which (s)he would receive no immediate benefit. In brief, there is considerable uncertainty concerning the viability of penalties for sovereign default. Thus, empirical evidence regarding such penalties warrants attention.

Unfortunately, there are only a limited number of empirical studies concerning such penalties. Ozler (1993) provides evidence of positive, albeit small, premia charged to countries with default histories. Cline (1987) notes that Bolivia and Peru experienced interruptions in their flows of short-term trade credits subsequent to debt renegotiation. In a recent paper, Rose (2002) provides empirical support for the role of trade as a sovereign enforcement mechanism. His 
paper shows that sovereign Paris Club reschedulings are followed by economically and statistically significant reductions in international trade.

The evidence of Cline and Rose centers on the interruption of international trade as a mechanism for sovereign debt repayment. If one believes that the primary penalties for enforcing sovereign debt obligations are trade related, then creditors originating from nations with strong bilateral trade ties with a debtor nation should have a comparative advantage in lending to that nation.

In this short paper, we explore this idea. We first present a theoretical model of international lending where a debtor optimally chooses its borrowing from different creditors. These creditors are identical except that they are located in countries which differ by the strength of their bilateral trade ties with the debtor. We show that in equilibrium, the pattern of borrowing favors the creditor with higher bilateral trade volume with the debtor. We then test and corroborate this idea using an annual panel data set including bilateral trade and international banking claims from 20 creditor and 149 debtor countries from 1986 through 1999. Using instrumental variable (and other) techniques, we find a significantly positive effect of bilateral trade on bilateral lending patterns. That is, debtors tend to borrow more from creditors with whom they share more international trade ties.

Our theoretical model is presented in next section. We then present the data set and methodology and test the model. The paper ends with a brief summary.

\section{2: A Model of Sovereign Borrowing with Trade-Related Default Penalties}


In this section we develop a simple borrowing model in which a sovereign debtor allocates its borrowing across different creditor nations, when default penalties are based on proportional losses in bilateral gains from trade.

We assume that there are three countries: one borrower country, $i$, and two creditor countries, $a$ and $b$. Let $r$ represent one plus the world risk-free interest rate. All countries are assumed to be small and therefore take $r$ as given. Lending banks in the creditor countries are risk-neutral and therefore willing to extend unlimited funds at levels consistent with an expected return equal to $r$.

The model has two periods. In the first period, the representative agent in lender country $j$ $(j=a, b)$ extends a loan of magnitude $L_{i j}$ in return for the promise of a fixed payment $D_{i j}$ in the second period. In the second period, the agent in debtor country $i$ makes its default decisions. If the debtor chooses to service its country $j$ debt it pays $D_{i j}$. If the debtor defaults, it suffers a penalty equal to a fraction $\theta$ of its gains from bilateral trade with country $j$, where $0<\theta<1$.

Bilateral gains from trade are exogenous and equal to $\gamma T_{i j}$, where $\gamma$ is a positive constant and $T_{i j}$ is a random variable reflecting total trade between country $i$ and country $j$ in the second period. Expectations of $T_{i j}$ are unbiased and satisfy

$$
T_{i j}=E_{1}\left(T_{i j}\right)+\varepsilon_{i}
$$

where $E_{1}\left(T_{i j}\right)$ represents the period one expected value of $T_{i j}$ and $\varepsilon_{i}$ is an i.i.d. disturbance term with expected value 0 and a symmetric and single-peaked-distribution on the interval $\varepsilon_{i} \in[\underline{\varepsilon}, \bar{\varepsilon}]$. Let $F(\varepsilon)$ represent the distribution of $\mathcal{\varepsilon}$, i.e. the probability that $\varepsilon_{i} \leq \mathcal{E}$, and 
$f(\varepsilon)$ represent its density. The creditor nations are assumed to only differ in their expected trade volume with the debtor country, with $E_{1}\left(T_{i a}\right)>E_{1}\left(T_{i b}\right)$.

The expected utility function of the representative agent in country $i$ satisfies

$$
E_{1}\left(U_{i}\right)=U\left(C_{i 1}\right)+\beta E_{1}\left(C_{i 2}\right)
$$

where $U^{\prime}>0, U^{\prime \prime}<0, C_{i t}$ represents consumption in country $i$ in period $t(t=1,2)$, and $\beta$ represents the debtor's discount rate. The specification that debtor utility is linear in expected second period consumption is made for analytic simplicity, but drives none of our results.

Debtor income, $Y_{i t}$, is exogenous in both periods. Debtor first-period consumption satisfies

$$
C_{i 1}=Y_{i 1}+L_{i a}+L_{i b}
$$

Since no new funds are obtained in period 2, the debtor's default decision on debts from each creditor nation is based on maximizing expected second period consumption. Conditional on service on its debt obligations to country $j$, debtor second-period consumption satisfies

$$
C_{i 2}=Y_{i 2}+\gamma T_{i j}-D_{i j}-g\left(D_{i k}, \varepsilon_{i}\right)
$$

where $j \neq k$ and $g\left(D_{i k}, \varepsilon_{i}\right)$ represents the cost of the debtor's utility-maximizing default decision on debt owed to country $k$.

Similarly, conditional on default on obligations to country $j$, debtor second-period consumption satisfies

$$
C_{i 2}=Y_{i 2}+(1-\theta) \gamma T_{i j}-g\left(D_{i k}, \varepsilon_{i}\right) .
$$

If follows that the debtor chooses to default on country $j$ when $D_{i j}>\theta \gamma T_{i j}$. 
Define $\varepsilon_{i j}^{*}$ as the realization of $\varepsilon_{i}$ that leaves the debtor indifferent between default and repayment. $\varepsilon_{i j}^{*}$ satisfies

$$
\varepsilon_{i j}^{*}=\frac{D_{i j}}{\theta \gamma}-E_{1}\left(T_{i j}\right)
$$

Equilibrium in the model is defined as the pair of debt obligations $\left(D_{i a}, D_{i b}\right)$ that maximize expected debtor utility subject to both creditors' zero profit conditions. The creditors' zero profit conditions satisfy

$$
D_{i j}=\frac{r L_{i j}}{1-F\left(\varepsilon_{i j}^{*}\right)}
$$

where $j=a, b$.

Utility maximization for the debtor can be characterized in terms of two decisions, the overall borrowing level, $L_{i}$, and the allocation of debt across the two creditors, $D_{i a}$ and $D_{i b}$. Consider first the allocation decision. Given total borrowing $L_{i}$, maximizing expected utility subject to the creditors' zero-profit conditions yields the first-order condition

$$
\varepsilon_{i a}^{*}=\varepsilon_{i b}^{*}
$$

Equation (1.8) suggests that the debtor maximizes expected utility by allocating its borrowing to equalize the probability of default across the two creditor nations. The intuition behind this result lies in the creditors' zero-profit conditions. Since the creditors' risk premia are symmetric functions of default risk, equalizing the marginal cost of the last dollar borrowed in each country implies equalizing the probability of default across the two countries.

Totally differentiating (1.8) with respect to $L_{i a}$ and $T_{i a}$ yields 


$$
\frac{d L_{i a}}{d E_{1}\left(T_{i a}\right)}=\frac{2 r}{\gamma \theta\left[1-F\left(\varepsilon_{i a}^{*}\right)\right]}>0 .
$$

Equation (1.9) yields our first result: Holding total lending constant, the share of lending originating in country $a$ is increasing in the expected volume of trade with country $a$.

Note that the result in equation (1.9) also implies that default decisions are identical expost. Consequently, let $\varepsilon_{i}^{*}$ represent the realization of $\varepsilon_{i}$ that leaves the debtor indifferent between default and debt service to both creditors. By equations (1.7) and (1.8) we obtain

$$
\varepsilon_{i}^{*}=\frac{1}{2}\left[\frac{D_{i}}{\gamma \theta}-\left[E_{1}\left(T_{i a}\right)+E_{1}\left(T_{i b}\right)\right]\right] .
$$

We can now confront the debtor's overall borrowing decision. Maximizing expected utility over the choice of $D_{i}$ subject to the creditors' zero-profit conditions and the debtor's optimal debt allocation rule yields the first order condition

$$
\left(\frac{U^{\prime}}{r}-\beta\right)\left(1-F^{*}\right)-\left(\frac{U^{\prime}}{r}\right)\left(\frac{f^{*} D_{i}}{2 \gamma \theta}\right)=0
$$

where $f^{*}$ and $F^{*}$ represent $f\left(\varepsilon_{i}^{*}\right)$ and $F\left(\varepsilon_{i}^{*}\right)$ respectively. Note that the first bracketed term will be positive when more borrowing would be desired if there were no default risk, a condition we assume to hold.

Totally differentiating with respect to $D_{i}$ and $E_{1}\left(T_{i a}\right)$ yields

$$
\frac{d D_{i}}{d E_{1}\left(T_{i a}\right)}=-\frac{\left(U^{\prime}+\frac{U^{\prime \prime}}{\gamma \theta}\right) f^{*}+\left(U^{\prime}+U^{\prime \prime}\right)\left(\frac{f^{*} \cdot D_{i}}{\gamma \theta}\right)-\beta r f^{*}}{2 r \frac{\partial^{2} U}{\partial D_{i}^{2}}}
$$


where the denominator can be signed as negative by the debtor's second order condition.

The term in the numerator can be signed as positive when the utility function is not too concave. The necessary and sufficient condition for $d D_{i} / d E_{1}\left(T_{i a}\right) \geq 0$ is

$$
\left|U^{\prime \prime}\right| \leq \frac{\left(U^{\prime}-\beta r\right) \gamma \theta f^{*}+U^{\prime} f^{*}{ }^{\prime} D_{i}}{f^{*}+f^{*} D_{i}} .
$$

Given satisfaction of this condition, equation (1.12) shows that holding all else equal, an increase in $E_{1}\left(T_{i a}\right)$ increases the total level of borrowing by the debtor.

Our results demonstrate that an increase in the expected volume of bilateral trade with an individual country is associated with both an increase in overall borrowing and an increase in the share of overall borrowing originating in that country. Consequently, the model predicts a positive correlation between expected bilateral trade volumes and bilateral lending. In the next section, we test this prediction.

\section{3: Empirics}

\section{Gravity Methodology}

We are interested in estimating the effect of international trade on international debt. However, international borrowing may itself encourage trade; alternatively, both borrowing and trade may be jointly driven by common factors. That is, it is important for us to consider the possibility that international borrowing and trade are simultaneously determined.

We solve this problem using instrumental variables. The popular "gravity" model of bilateral international trade provides a wealth of potential instrumental variables. Many variables which are known to be important determinants of international trade are unlikely to be important 
determinants of international lending patterns. For instance, a pair of landlocked countries engages in less international trade, while a pair of physically large countries or those which share a common land border trade more. But international lending patterns are unlikely to be affected by such features. We use such variables as instrumental variables for trade in a model of bilateral lending.

Since conditions that lead two countries to be more integrated are likely to lead to more financial activity between them, our specification for bilateral international borrowing levels follows the gravity model of international trade closely:

$$
\begin{aligned}
\ln \left(C_{\mathrm{ijt}}\right) & =\beta_{1} \ln \left(\mathrm{Y}_{\mathrm{i}} \mathrm{Y}_{\mathrm{j}}\right)_{\mathrm{t}}+\beta_{2} \ln \left(\mathrm{Y}_{\mathrm{i}} \mathrm{Y}_{\mathrm{j}} / \operatorname{Pop}_{\mathrm{i}} \mathrm{Pop}_{\mathrm{j}}\right)_{\mathrm{t}}+\beta_{3} \operatorname{lnD}_{\mathrm{ij}}+\beta_{4} \operatorname{Lang}_{\mathrm{ij}}+\beta_{5} \operatorname{Cont}_{\mathrm{ij}}+\beta_{6} \mathrm{FTA}_{\mathrm{ijt}} \\
& +\beta_{7} \operatorname{Landl}_{\mathrm{ij}}+\beta_{8} \operatorname{Island}_{\mathrm{ij}}+\beta_{9} \ln \left(\text { Area }_{\mathrm{i}} \mathrm{Area}_{\mathrm{j}}\right)+\beta_{10} \operatorname{ComCol}_{\mathrm{ij}}+\beta_{11} \operatorname{CurCol}_{\mathrm{ijt}} \\
& +\beta_{12} \text { Colony }_{\mathrm{ij}}+\beta_{13} \operatorname{ComNatij}+\beta_{14} \mathrm{CU}_{\mathrm{ijt}}+\gamma_{\tau} \cdot \mathrm{T}_{\tau \mathrm{t}}+\varphi \ln \left(\mathrm{X}_{\mathrm{ijt}}\right)+\varepsilon_{\mathrm{ijt}}
\end{aligned}
$$

where $i$ and $\mathrm{j}$ denotes countries, $\mathrm{t}$ denotes time, and the variables are defined as:

- $\mathrm{C}_{\mathrm{ijt}}$ denotes the value of real lending from $\mathrm{i}$ to $\mathrm{j}$ at time $\mathrm{t}$,

- $\mathrm{X}_{\mathrm{ijt}}$ denotes the average value of real bilateral trade between $\mathrm{i}$ and $\mathrm{j}$ at time $\mathrm{t}$,

- $\mathrm{Y}$ is real GDP,

- Pop is population,

- D is the distance between $i$ and $j$,

- Lang is a binary variable which is unity if $i$ and $j$ have a common language,

- Cont is a binary variable which is unity if $i$ and $j$ share a land border,

- FTA is a binary variable which is unity if $i$ and $j$ belong to the same regional trade agreement,

- Landl is the number of landlocked countries in the country-pair $(0,1$, or 2$)$.

- Island is the number of island nations in the pair $(0,1$, or 2$)$,

- Area is the land mass of the country, 
- ComCol is a binary variable which is unity if $\mathrm{i}$ and $\mathrm{j}$ were ever colonies after 1945 with the same colonizer,

- CurCol is a binary variable which is unity if $\mathrm{i}$ and $\mathrm{j}$ are colonies at time $\mathrm{t}$,

- Colony is a binary variable which is unity if $\mathrm{i}$ ever colonized $\mathrm{j}$ or vice versa,

- ComNat is a binary variable which is unity if $\mathrm{i}$ and $\mathrm{j}$ remained part of the same nation during the sample (e.g., the UK and Bermuda),

- $\mathrm{CU}$ is a binary variable which is unity if $\mathrm{i}$ and $\mathrm{j}$ use the same currency at time $\mathrm{t}$,

- $\mathrm{T}_{\tau \mathrm{t}}$ is a comprehensive set of year-specific intercepts,

- $\quad \beta$ and $\gamma$ are vectors of nuisance coefficients, and

- $\varepsilon_{\mathrm{ij}}$ represents the myriad other influences on bilateral credit, assumed to be well behaved.

The coefficient of interest to us is $\varphi$, the effect of bilateral trade between countries $i$ and $j$ on commercial bank claims by creditor country $j$ on debtor nation $i$.

We estimate the model with a number of techniques below. We begin by using ordinary least squares with standard errors that are robust to clustering (since pairs of countries are likely to be highly dependent across years). We then use instrumental variables, dropping some of the regressors from the right-hand side of the equation and using them as instrumental variables. Finally, we employ fixed- and random-effects panel data estimators, with and without instrumental variables. We use both fixed and random effects estimators extensively below.

\section{The Data Set}

We use a subset of the panel data set of Glick and Rose (2002); the interested reader is referred to Glick and Rose for more details.

For the regressand we use consolidated foreign claims of reporting banks on individual countries. These bank loans are provided by the BIS in millions of American dollars for twenty creditor countries and almost 150 borrowing countries. ${ }^{\square}$ Not all of the areas covered are 
countries in the conventional sense of the word; we use the term "country" simply for convenience. (The creditor countries and debtor countries are listed in the appendix.) The data are provided semi-annually from 1986; we average the data to annual series by simple averaging. We convert nominal bank claims to a real series by deflating by the American CPI (19821984=1). Almost half the claims are reported to be zero. This makes the log transformation potentially important and questionable; we investigate it further below.

The most important regressor is the level of international trade. We use bilateral trade flows taken from the IMF's Direction of Trade data set, deflated by the American CPI. To this

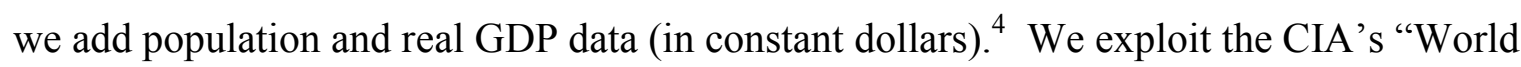
Factbook" for a number of country-specific variables. These include: latitude and longitude, land area, landlocked and island status, physically contiguous neighbors, language, colonizers, and dates of independence. We use these to create great-circle distance and our other controls. We obtain data from the World Trade Organization to create an indicator of regional trade agreements, and include: EEC/EC/EU; US-Israel FTA; NAFTA; CACM; CARICOM; PATCRA; ANZCERTA; ASEAN, SPARTECA, and Mercosur. Finally, we add the Glick and Rose (2002) currency union dummy variable.

Descriptive statistics for the data set are tabulated in the appendix.

\section{Results}

We begin our investigation by estimating (14) with OLS. Our results appear in Table 1.

Our default estimates include the entire set of regressors (i.e., all fourteen coefficients are estimated as well as the set of time-specific intercepts). In this specification, the estimate of the all-important $\varphi$ coefficient is .54, with a robust standard error of .04. This result is not only 
consistent with our theory, but is highly significant. With a t-statistic of over 15 , the coefficient is different from zero at any reasonable level of statistical significance. The effect is also economically significant; an increase in trade of $1 \%$ is associated with an increase in bilateral lending of over .5\%, all other things being equal.

The rest of the table provides a series of robustness checks. For instance, the second row reports $\varphi$ if the other controls are dropped from the equation (i.e., we set $\beta=\gamma=0$ ); in this case, the effect is even more significant. Since many of the creditor countries have not extended loans to some of the debtor countries, many observations of the dependent variable are zero and are thus dropped from the equation estimated in natural logarithms. Therefore, the third and fourth rows of the table report comparable estimates of $\varphi$ when both trade and bank claims are included in untransformed levels. Yet $\varphi$ remains statistically significant when the key relationship is estimated in levels.

The fifth and sixth rows of the table move away from panel data analysis to cover only cross-sections for two years in the middle of the sample, 1990 and 1995. However, the results are essentially unchanged from the default specification. The seventh and final row includes only observations between industrial countries (i.e., those with IFS country codes less than 200). Again, the results are essentially unchanged.

To summarize, the effect of international trade on bank claims seems positive, significant, and robust in simple OLS estimation. The question is whether this result stands up to greater econometric scrutiny.

\section{Results}


We now proceed to instrumental variables estimation. We use five instrumental variables for (the log of) trade: (the log of) distance between the countries; the land border dummy; the number of landlocked countries; the number of island nations; and the log of the product of the countries' area. We accordingly set the appropriate $\beta$ coefficients to zero (i.e., drop them from the equation, leaving the remaining variables as controls). The estimates are tabulated in Table 2a.

Despite the use of instrumental variables that are both plausibly exogenous and correlated with trade, the key results do not change with IV estimation. The default estimate is somewhat smaller, averaging perhaps .4. But it remains economically and statistically significant; it is also robust to a number of econometric perturbations.

Table $2 \mathrm{~b}$ reports sensitivity analysis with respect to the set of instrumental variables. Instead of the five geographic variables, we use three whose coefficients are usually insignificant in OLS estimates of equation (14): the common language dummy; the regional trade agreement dummy; and the same nation dummy. Again, the estimates of $\varphi$ seem economically and statistically significant

The middle column of Table 3 adds a control for the (log of the) total credit extended by the creditor country, as suggested by our theoretical analysis; the right-hand column controls for the (log of) total debt incurred by the debtor country. Again, the results remain economically and statistically significant.

Finally, Table 4 reports results when panel estimators are used instead of more traditional regressions. The middle columns report OLS fixed- and random-effects estimates of $\varphi$ for a variety of different specifications. The right-hand column reports instrumental variables estimates using a random effects estimator (the fixed-effect estimator is infeasible since the 
geographic variables are time-invariant). Yet despite all the econometric firepower, the estimate of $\varphi$ remains significant; it has a t-statistic of almost 9 and an economically large effect?

We conclude that our hypothesis that bank credit is extended across international borders along the lines of international trade is corroborated.

\section{4: Summary}

It is plausible to believe that countries service their foreign debts at least in part to avoid the reduced trade that typically follows international default. If so, sovereign borrowers will enjoy superior credit terms from creditor countries for which this penalty is disproportionately high. In this paper we have provided a simple theoretical model which formalizes this intuition. We have also empirically investigated and confirmed the hypothesis that international trade patterns determine lending patterns.

It is important to note that while our theoretical model was based on an explicit default penalty, our empirical evidence does not necessarily refute pure "reputation-based" models of sovereign debt. For example, in a recent paper Eaton and Kletzer (2002) demonstrate that purely reputation-based sovereign lending arrangements are sustainable based upon the ability of one nation to smooth the consumption bundle of the other over time. Since bilateral trade volume levels may reflect inter-temporal gains from trade, our results are likely consistent with their model.

In future work it would be interesting to extend this analysis to other forms of international lending, above and beyond bank loans. We thank this is a good place to pass the torch to others. 
Table 1: OLS Estimates of Effect of Trade on Claims

\begin{tabular}{|l|c|}
\hline & $\varphi$ \\
\hline Default & $.54(.04)$ \\
\hline Without controls & $.75(.02)$ \\
\hline Levels & $.0001(.00003)$ \\
\hline Levels without controls & $.0001(.00003)$ \\
\hline 1990 & $.51(.05)$ \\
\hline 1995 & $.53(.07)$ \\
\hline Only industrial debtors & $.74(.04)$ \\
\hline
\end{tabular}

Equation estimated is Claims $\mathrm{i}_{\mathrm{i}, \mathrm{t}}=\varphi \operatorname{Trade}_{\mathrm{i}, \mathrm{t}, \mathrm{t}}+\beta \mathrm{X}_{\mathrm{i}, \mathrm{j}, \mathrm{t}}+\varepsilon_{\mathrm{i}, \mathrm{j}, \mathrm{t}}$

Robust standard errors (clustered by country-pairs) recorded in parentheses.

Intercepts and year effects not recorded.

Table 2a: IV Estimates of Effect of Trade on Claims, Geographic Instruments

\begin{tabular}{|l|c|}
\hline & $\varphi$ \\
\hline Default & $.41(.07)$ \\
\hline Without controls & $.50(.04)$ \\
\hline Levels & $.00006(.00001)$ \\
\hline Levels without controls & $.00007(.00002)$ \\
\hline 1990 & $.52(.10)$ \\
\hline 1995 & $.40(.10)$ \\
\hline Only industrial debtors & $1.03(.07)$ \\
\hline
\end{tabular}

Equation estimated is Claims $_{\mathrm{i}, \mathrm{j}, \mathrm{t}}=\varphi \operatorname{Trade}_{\mathrm{i}, \mathrm{j}, \mathrm{t}}+\beta \mathrm{W}_{\mathrm{i}, \mathrm{j}, \mathrm{t}}+\varepsilon_{\mathrm{i}, \mathrm{j}, \mathrm{t}}$

Robust standard errors (clustered by country-pairs) recorded in parentheses.

Intercepts and year effects not recorded.

Instrumental variables for trade are: distance; land border; number landlocked; number island nations; $\log$ of area.

Table 2b: IV Estimates of Effect of Trade on Claims, Excludable Instruments

\begin{tabular}{|l|c|}
\hline & $\varphi$ \\
\hline Default & $.80(.40)$ \\
\hline Without controls & $.83(.07)$ \\
\hline Levels & $.00004(.00001)$ \\
\hline Levels without controls & $.00005(.00001)$ \\
\hline 1990 & $.59(.37)$ \\
\hline 1995 & $1.13(.49)$ \\
\hline Only industrial debtors & $.79(.29)$ \\
\hline
\end{tabular}

Equation estimated is Claims $_{\mathrm{i}, \mathrm{j}, \mathrm{t}}=\varphi \operatorname{Trade}_{\mathrm{i}, \mathrm{j}, \mathrm{t}}+\beta \mathrm{Z}_{\mathrm{i}, \mathrm{j}, \mathrm{t}}+\varepsilon_{\mathrm{i}, \mathrm{j}, \mathrm{t}}$

Robust standard errors (clustered by country-pairs) recorded in parentheses.

Intercepts and year effects not recorded.

Instrumental variables for trade are: common language; regional trade agreement; same nation. 
Table 3: IV Estimates of Effect of Trade on Claims, Controlling for Total Claims/Debt

\begin{tabular}{|l|c|c|}
\hline Control: & Total Claims & Total Debt \\
\hline Default & $.40(.07)$ & $.42(.07)$ \\
\hline Without controls & $.42(.04)$ & $.27(.04)$ \\
\hline Levels & $.00005(.000004)$ & $.00006(.00002)$ \\
\hline Levels without controls & $.00005(.000006)$ & $.00006(.00002)$ \\
\hline 1990 & $.47(.10)$ & $.56(.09)$ \\
\hline 1995 & $.37(.10)$ & $.42(.10)$ \\
\hline Only industrial debtors & $.48(.23)$ & $1.10(.20)$ \\
\hline OLS & $.29(.03)$ & $.39(.02)$ \\
\hline
\end{tabular}

Equation estimated is Claims $_{\mathrm{i}, \mathrm{j}, \mathrm{t}}=\varphi \operatorname{Trade}_{\mathrm{i}, \mathrm{j}, \mathrm{t}}+\beta \mathrm{W}_{\mathrm{i}, \mathrm{j}, \mathrm{t}}+\varepsilon_{\mathrm{i}, \mathrm{j}, \mathrm{t}}$

Robust standard errors (clustered by country-pairs) recorded in parentheses.

Intercepts and year effects not recorded.

Instrumental variables for trade are: distance; land border; number landlocked; number island nations; log of area.

Table 4: IV Estimates of Effect of Trade Level on Claims, Panel Estimators

\begin{tabular}{|l|c|c|c|}
\hline Estimator: & OLS, RE & OLS, FE & IV, RE \\
\hline Default & $.31(.01)$ & $.19(.02)$ & $.52(.06)$ \\
\hline Without controls & $.38(.01)$ & $.19(.01)$ & $.52(.03)$ \\
\hline Levels & $.00003(.000001)$ & $.00002(.000001)$ & $.00006(.00001)$ \\
\hline Levels without controls & $.00003(.000001)$ & $.00002(.000001)$ & $.00007(.000003)$ \\
\hline Only industrial debtors & $.46(.06)$ & $.28(.07)$ & $.96(.19)$ \\
\hline
\end{tabular}

Equation estimated is Claims $_{\mathrm{i}, \mathrm{j}, \mathrm{t}}=\varphi \mathrm{Trade}_{\mathrm{i}, \mathrm{j}, \mathrm{t}}+\beta \mathrm{W}_{\mathrm{i}, \mathrm{j}, \mathrm{t}}+\varepsilon_{\mathrm{i}, \mathrm{j}, \mathrm{t}}$

Robust standard errors (clustered by country-pairs) recorded in parentheses.

Intercepts and year effects not recorded.

Instrumental variables for trade are: distance; land border; number landlocked; number island nations; log of area. 


\section{References}

Bulow, Jeremy and Kenneth Rogoff (1989a) "A Constant Recontracting Model of Sovereign Debt” Journal of Political Economy 97(1), 155-178.

Bulow, Jeremy and Kenneth Rogoff (1989b) "Sovereign Debt: Is to Forgive to Forget?" American Economic Review 79(1), 43-50.

Cline, William R. (1987) Mobilizing Bank Lending to Debtor Countries, Institute for International Economics, Washington D.C.

Eaton, Jonathan and Kenneth M. Kletzer (2002) UCSC working paper.

Glick, Reuven and Andrew K. Rose (2002) “Does a Currency Union Affect Trade?” European Economic Review forthcoming.

Kletzer, Kenneth M. and Brian D. Wright (2000) "Sovereign Debt as Intertemporal Barter" American Economic Review 90(3), 621-639.

Ozler, Sule (1993) "Have Commercial Banks Ignored History?" American Economic Review 83(3), 608-620.

Rose, Andrew K. (2002) “One Reason Countries Pay Their Debts: Renegotiation and International Trade” NBER Working Paper 8853. 
Appendix 1: Descriptive Statistics

\begin{tabular}{|r|c|c|c|c|c|}
\hline & Sample & Mean & Std. Dev. & Min & Max \\
\hline Claims & 31,787 & 561. & 3529. & 0 & 146061. \\
\hline Log real claims & 19,769 & 3.69 & 2.53 & -1.20 & 11.5 \\
\hline Log real trade & 28.809 & 11.6 & 2.81 & -.55 & 20.3 \\
\hline Controls: Log distance & 28,809 & 8.32 & .59 & 5.37 & 9.41 \\
\hline Log real GDP & 25,126 & 49.6 & 2.50 & 42.3 & 58.0 \\
\hline Log real GDP per capita & 25,102 & 17.3 & 1.07 & 14.1 & 21.1 \\
\hline Common land border & 28.809 & .003 & .053 & 0 & 1 \\
\hline Common language & 28,809 & .173 & .379 & 0 & 1 \\
\hline Log areas & 28,809 & 23.8 & 3.25 & 12.20 & 32.3 \\
\hline \# landlocked & 28,809 & .286 & .496 & 0 & 2 \\
\hline \# islands & 28,809 & .301 & .489 & 0 & 2 \\
\hline Regional Trade Agreement & 31,787 & .009 & .094 & 0 & 1 \\
\hline Same nation & 28,809 & .003 & .054 & 0 & 1 \\
\hline Colonial history & 28,809 & .051 & .221 & 0 & 1 \\
\hline Current Colony & 28,809 &, 003 &, 057 & 0 & 1 \\
\hline & & & & & \\
\hline
\end{tabular}

Appendix 2: Creditor Countries with Claims Reported

\begin{tabular}{|l|l|l|l|}
\hline US & UK & Austria & Belgium \\
\hline Denmark & France & Germany & Italy \\
\hline Netherlands & Switzerland & Sweden & Canada \\
\hline Japan & Finland & Greece & Iceland \\
\hline Ireland & Malta & Portugal & Spain \\
\hline
\end{tabular}




\begin{tabular}{|c|c|c|}
\hline Afghanistan & Ghana & Nigeria \\
\hline Albania & Gibraltar & Oman \\
\hline Algeria & Greece & Pakistan \\
\hline Angola & Grenada & Panama \\
\hline Argentina & Guatemala & Papua New Guinea \\
\hline Australia & Guinea & Paraguay \\
\hline Bahamas & Guinea Bissau & Peru \\
\hline Bahrain & Guyana & Philippines \\
\hline Bangladesh & Haiti & Poland \\
\hline Barbados & Honduras & Portugal \\
\hline Belize & Hong Kong & Qatar \\
\hline Benin & Hungary & Romania \\
\hline Bermuda & Iceland & Rwanda \\
\hline Bhutan & India & Sao Tome and Principe \\
\hline Bolivia & Indonesia & Saudi Arabia \\
\hline Botswana & Iran & Senegal \\
\hline Brazil & Iraq & Seychelles \\
\hline Brunei & Israel & Sierra Leone \\
\hline Bulgaria & Jamaica & Singapore \\
\hline Burkina Faso & Jordan & Solomon Islands \\
\hline Burundi & Kenya & Somalia \\
\hline Cambodia & Kiribati & South Africa \\
\hline Cameroon & Kuwait & South Korea \\
\hline Cape Verde & Laos & Sri Lanka \\
\hline Cayman Islands & Lebanon & St Lucia \\
\hline Central African Rep. & Lesotho & St Vincent \\
\hline Chad & Liberia & St Helena \\
\hline Chile & Libya & Sudan \\
\hline China & Macau & Surinam \\
\hline Colombia & Madagascar & Swaziland \\
\hline Comoros Islands & Malawi & Syria \\
\hline Congo & Malaysia & Tanzania \\
\hline Congo Democratic Republic & Maldives & Thailand \\
\hline Costa Rica & Mali & Togo \\
\hline Cote d'Ivoire & Malta & Tonga \\
\hline Cuba & Mauritania & Trinidad and Tobago \\
\hline Cyprus & Mauritius & Tunisia \\
\hline Djibouti & Mexico & Turkey \\
\hline Dominica & Mongolia & Uganda \\
\hline Dominican Republic & Morocco & United Arab Emirates \\
\hline Ecuador & Mozambique & Uruguay \\
\hline Egypt & Myanmar & Vanuatu \\
\hline El Salvador & Namibia & Venezuela \\
\hline Equatorial Guinea & Nauru & Vietnam \\
\hline Ethiopia & Nepal & Western Samoa \\
\hline Falkland Islands & Netherlands Antilles & Yemen \\
\hline Fiji & New Caledonia & Yugoslavia \\
\hline French Polynesia & New Zealand & Zambia \\
\hline Gabon & Nicaragua & Zimbabwe \\
\hline Gambia & Niger & \\
\hline
\end{tabular}




\section{Endnotes}

${ }^{1}$ In addition, we assume that the probability of default by the debtor is less than one-half, so that $f^{*} ' \geq 0$.

${ }^{2}$ These data are available at: http://www.bis.org/publ/qcsv0206/hanx9b.csv and are part of the International Banking Statistics published regularly in the BIS Quarterly Review. For technical reasons we usually ignore a few observations from Ireland and Spain; adding these makes little difference in general to our results.

${ }^{3}$ Bilateral trade on FOB exports and CIF imports is recorded in American dollars; we deflate trade by the American CPI. We create an average value of bilateral trade between a pair of countries by averaging all of the four possible measures potentially available.

${ }^{4}$ Wherever possible, we use "World Development Indicators" (taken from the World Bank's WDI 2000 CD-ROM) data. When the data are unavailable from the World Bank, we fill in missing observations with comparables from the Penn World Table Mark 5.6, and (when all else fails), from the IMF's "International Financial Statistics". The series have been checked and corrected for errors.

${ }^{5}$ Box-Cox tests imply that the natural logarithmic transformation is quite reasonable, and that the level transformation is rejected in favor of the log transform.

${ }^{6}$ If we use lags (e.g., of the GDP terms) as instrumental variables, our key result of a positive effect of trade on borrowing is not changed.

${ }^{7}$ Lending may be motivated by servicing FDI, rather than the sovereign risk issues considered in the theory above. To test this, we add a control in the form of the natural logarithm of FDI sourced from the creditor country. We obtained the bilateral FDI data from the OECD's International Direct Investments Yearbook 1980-2000. This data set is annual and unavailable for many countries in our sample, containing only some 2,600 observations. When we add this control to our default IV regression (in logs, with controls) its coefficient is indeed positive and significant. Still, the log of trade retains an economically and statistically significant coefficient of .62 (with a robust standard error of .11). 